\title{
Soil fertility status of cassava fields treated by integrated application of manure and NPK fertilizer in Zambia
}

\author{
Gizachew Kebede Biratu ${ }^{1,2,3^{*}}$ (D), Eyasu Elias ${ }^{1}$ and Pheneas Ntawuruhunga ${ }^{2}$
}

\begin{abstract}
Background: Cassava is a heavy feeder crop that can cause serious depletion to soil nutrient stocks. This research aimed to explore soil fertility status and nutrient supply capacity at different growth stages of cassava fields under combined application of organic manure and NPK fertilizers in two agroecologies of Zambia. Topsoil (0-20 cm) samples were collected from cassava fields treated with factorial combination of four levels of chicken manure $(0,1.4,2.8$, and 4.2 ton $\mathrm{ha}^{-1}$ ) and four levels of NPK (control, 50N-11 P-41.5K, 100N-22P-83K, and 150N-33P-124.5P). The soils were sampled under the cassava canopy to determine soil pH, available phosphorus (AP), total nitrogen (TN), organic carbon (OC), cation exchange capacity (CEC), exchangeable bases and micronutrients ( $\mathrm{Fe}, \mathrm{Cu}, \mathrm{Mn}$, and $\mathrm{Zn}$ ). The samples were collected before planting andafter establishment at 4, 8, and 12 months after planting (MAP).

Results: Manure application significantly $(p<0.05)$ increased soil $\mathrm{pH}$, while the application of mineral fertilizer reduced soil $\mathrm{pH}$ at all the plant growth stages. Similarly, manure application and their interaction with mineral fertilizer increased OC and TN levels, especially at harvest. By contrast, OC and TN decreased with the application of mineral fertilizer. AP levels increased following the application of both fertilizers. In addition, manure application significantly increased soil Zn content from $0.69 \mathrm{mg} \mathrm{kg}^{-1}$ in the control to $3.54 \mathrm{mg} \mathrm{kg}^{-1}$ for the highest level of manure at harvest. The interaction between manure and NPK significantly affected Fe and Mn content in the soil.
\end{abstract}

Conclusion: The results revealed that sole chicken manure application or its combination with mineral fertilizer improves soil nutrient status of cassava fields in Zambian condition.

Keywords: Chicken manure, Macronutrients, Micronutrients, NPK fertilizers, Soil nutrient

\section{Introduction}

More than half of the rural Africans directly depend on crops that are grown locally in their surroundings. However, land and labor productivity are among the least compared to the rest of the world (Bationo et al. 2007). Smallholder farmers in Sub-Saharan Africa (SSA) apply inadequate amounts of nutrients to their farms, which results in overuses of the soil nutrient stocks by plants leading to gradual soil nutrient depletion and eventual soil degradation (Ayoola and Makinde 2014). As a result,

\footnotetext{
*Correspondence: gizachewk2006@yahoo.com

${ }^{1}$ Center for Environmental Science, College of Natural and Computational Science, Addis Ababa University, P O box 3131, Addis Ababa, Ethiopia

Full list of author information is available at the end of the article
}

per capita food production is declining in Africa, mainly in SSA, while it is increasing in the other world (Bationo et al. 2011). Because of this, the long term agricultural productivity in the continent is under threat as crop harvest suffer from continuous soil nutrient mining (Namoi et al. 2014).

As in many counties of SSA, cassava (Manihot esculenta Crantz) is one of the mainfood staples in Zambia (Biratu et al. 2018; Ntawuruhunga et al. 2013). It is also an important income generating and food security crop in Africa (Carsky and Toukourou 2005). Cassava is drought resistant and less affected by adverse climatic conditions, hinting at an expected expansion in its production especially when climate change threatens crop production in Africa (Howeler et al. 2013). However, cassava is 
a heavy feeder crop that can cause serious soil degradation because of excess nutrient removal (Howeler 2011). It extracts huge amount of soil nutrients, mainly potassium, followed by nitrogen and phosphorus (Imas and John 2013; Pongsivapai et al. 2016). It is then believed that just by applying mineral fertilizer alone, 10 to 16 ton $\mathrm{ha}^{-1}$ of fresh cassava root yield increase is possible for smallholder African farmers (Hauser et al. 2014).

Because of the large gap between the agronomic potential and the actual cassava yield at farmers' field (Chianu et al. 2012), there is a huge need for increased fertilizer application in Zambia and/or in other parts of SSA. Cassava production is expected to increase globally because of its increasing demand in industrial production of bioenergy (bioethanol), animal feed (Pongsivapai et al. 2016) and quality starch (Anyanwu et al. 2015). This huge demand for cassava will not be met unless adequate fertilizer input (organic and/or mineral fertilizer) is used to boost its production (Osundare 2014). Mineral fertilizers are usually exact in their content and depends on types of nutrients supplied. It also releases nutrient elements faster into the soils with limited residual effect (Makinde and Agboola 2002). On the other hand, organic fertilizers can supply both macro and micro nutrients at the same time and slowly releasing nutrient elements over long period of time. Their long term effects include improvement in soil structure, soil water content and cation exchange capacity (Edet et al. 2013). With separate application of either types of fertilizer, it is difficult to utilize the immediate availability of plant nutrients from mineral fertilizers and long term benefits of organic fertilizers. Alternatively, combined application of these two types has been considered as effective management strategy (Fairhurst 2012). However, few fertilizer trials on cassava have been conducted in Africa (Carsky and Toukourou 2005) leading to limited understanding of soils under cassava field treated by the combination of organic and inorganic fertilizer. Furthermore, how combined use of organic and mineral fertilizers affect soil nutrient status across growth stages of cassava has been less understood. Therefore, this study aimed to: (1) understand the soil nutrient status across different cassava growth stages and (2) explore the short term soil fertility variation in cassava field streated by combined application of chicken manure and NPK fertilizers in Zambia.

\section{Materials and methods}

\section{Description of the study sites}

The experiment was carried out at two sites (Fig. 1). The first site was the Zambian Agricultural Research Institute (ZARI) Mansa Station, located at $28^{\circ} 56^{\prime} 33.4^{\prime \prime} \mathrm{E}$ and $11^{\circ} 14^{\prime} 30.2^{\prime \prime} \mathrm{S}$ in Mansa District of Luapula Province. The second was the Kabangwe Station of the International
Institute of Tropical Agriculture (IITA), located at $28^{\circ} 18^{\prime} 26.9^{\prime \prime} \mathrm{E}$ and $15^{\circ} 18^{\prime} 11.6^{\prime \prime} \mathrm{S}$ at the outskirt of Lusaka in Chibombo District, Central Province of Zambia. Mansa is in the agroecological zone III, while Kabangwe is situated in agroecological zone II of Zambia, which are divided based on rainfall and soil types (JAICAF 2008). Zone II is an area that receives an annual rainfall between 800 and $1000 \mathrm{~mm}$, but the zone III is a high rainfall area receiving more than $1000 \mathrm{~mm}$ of rainfall per annum (Aregheore 2009). However, the $2015 / 2016$ cropping season was an El Niño season in Zambia. This brought minimal rainfall in the central and southern part of the country, while the northern part still received appreciable amount of rain. As a result, from 23/11/2015 to $22 / 11 / 2016$ the Kabangwe site recorded only $422.9 \mathrm{~mm}$ of rainfall, while Mansa recorded $1245.6 \mathrm{~mm}$. The country as a whole is situated at the central African plateau and there is no significant difference (1246 m.a.s.l-ZARI Mansa and 1204 m.a.s.l-Kabangwe) in the elevation between the two research sites. According to the Zambian Environmental Management Authority-ZEMA (2013), Mansa district has a tropical continental climatic type, which is characterized by a cold dry season between May and July, hot and dry between August and October, and wet and dry between November and April. Gleysols dominate the soils of Mansa, but there are also acrisols and leptosols in some places. The soils of Mansa are generally leached because of the high rainfall in the area and with typical Miombo wood land vegetation. The dominant soil in the central plateau area is the Sandveld-where by the top soil is mostly dominated by sandy soil covering the clay sub-soil underneath with laterite (iron reach sub-surface horizon) (FAO 2008).

\section{Experimental design}

In order to understand the soil nutrient status under the cassava plots, $4 \times 4$ factorial field experiment wasset in Randomized Complete Block Design (RCBD) with three replications at both sites. The treatments were four levels of chicken manure; the control $\left(\mathrm{O}_{0}\right)$, 1.4-ton ha ${ }^{-1}$ $\left(\mathrm{O}_{1}\right)$, 2.8-ton ha ${ }^{-1}\left(\mathrm{O}_{2}\right)$ and 4.2-ton ha ${ }^{-1}\left(\mathrm{O}_{3}\right)$, combined with four levels of NPK; control $\left(\mathrm{M}_{0}\right), 50-11-41.5 \mathrm{~kg}$ $\mathrm{N}-\mathrm{P}-\mathrm{K} \mathrm{ha}^{-1}\left(\mathrm{M}_{1}\right), 100-22-83 \mathrm{~kg} \mathrm{~N}-\mathrm{P}-\mathrm{K} \mathrm{ha}^{-1}\left(\mathrm{M}_{2}\right)$, and 150-33-124.5 N-P-K kg ha ${ }^{-1}\left(\mathrm{M}_{3}\right)$ to give a total of 16 treatments. Chicken manure was chosen as soil amendment because it is high in nutrient content and readily available to smallholder households (Sileshi et al. 2017). We used 100-22-83 kg N-P-K ha ${ }^{-1}$ mineral fertilizer, which was recommended for cassava by Howeler et al. (2013) as a bench mark. We set two more levels by adding $50 \%$ and reducing $50 \%$ against the benchmark. The organic fertilizer (chicken manure) levels were set based on the nitrogen equivalent of these mineral fertilizer 


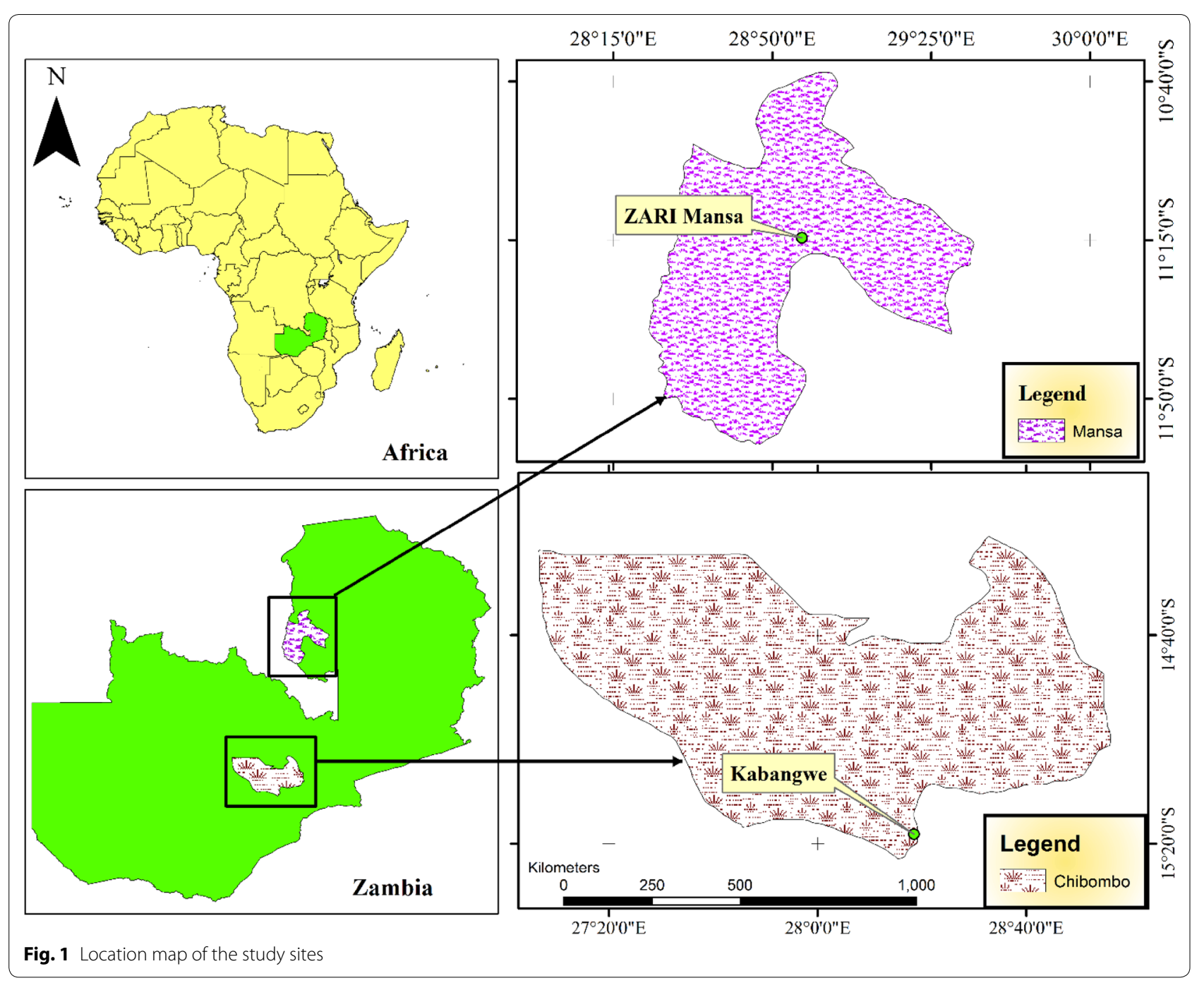

levels from lowest to the highest, respectively. Plot sizes were $5 \mathrm{~m} \times 5 \mathrm{~m}$ and cassava was planted at a $1 \mathrm{~m} \times 1 \mathrm{~m}$ standard inter and intra spacing, giving a total population of 25 plants per plot. Chicken manure (pure feces of chicken with no mixture of bedding material and feed) was freshly collected from caged, commercial layer farms, then properly dried and mixed to reach a homogenized mixture before application. Manure sample was also collected from properly mixed manure to determine its nutrient content for NPK and micronutrients.

Seed bed was prepared by ploughing and harrowed using disc plows mounted on tractors. Matured improved cassava variety "Mweru" cuttings of $25-30 \mathrm{~cm}$ in length, collected from the ZARI research station in Mansa, were planted. The NPK fertilizer was band applied as a single source fertilizer in the form of urea, triple superphosphate and potassium sulfate, respectively. Following a conventional practice for cassava, the manure was applied once at planting, while the $\mathrm{N}$ and $\mathrm{K}$ were applied into two splits. Fifty percent of these nutrients was and applied at one MAP and the remaining 50\% was applied at three MAP. P was all applied only once at one MAP. The trials were weeded by hand as needed.

\section{Soil sampling and analysis}

Topsoil samples $(0-20 \mathrm{~cm})$ were collected using an Edelman auger crisscrossing the experimental site and bulked together to get homogenized composite sample for each of the experimental sites before planting. After the establishment, samples were collected under the canopy of five cassava plants in the $3 \mathrm{~m} \times 3 \mathrm{~m}$ net plots following an ' $\mathrm{X}$ ' pattern and bulked together to give composite sample per plot. The sampling after establishment was done three times (at 4, 8 and $12 \mathrm{MAP}$ ) to get the soil nutrient 
condition at wet, dry, and at harvest seasons. After collection, samples were air-dried, ground, and pass through a $2 \mathrm{~mm}$ sieve to get the fine earth fraction $(<2 \mathrm{~mm}$ separates) and taken to the IITA's soil laboratory in Cameroon for wet chemistry analysis. Soil $\mathrm{pH}-\mathrm{H}_{2} \mathrm{O}$ (1:2.5 solution) was determined in a 1:2.5 (w/v) soil to water solution using $\mathrm{pH}$ meter, as outlined by McLean (1982). OC was determined by chromic acid digestion and spectrophotometric analysis as described by Heanes (1984). TN was determined from a wet acid digestion (Buondonno et al. 1995) and analyzed by colorimetric analysis (Anderson and Ingram 1993). Exchangeable bases $\left(\mathrm{Ca}^{2+}, \mathrm{Mg}^{2+}, \mathrm{K}^{+}\right.$ and $\left.\mathrm{Na}^{+}\right)$as well as available micronutrients $(\mathrm{Cu}, \mathrm{Zn}$, $\mathrm{Mn}, \mathrm{Fe}$ ) and AP were extracted using the Mehlich-3 procedure (Mehlich 1984), whereby the contents in the extracts were determined by flame photometry and atomic absorption spectrophotometry (AAS). Exchangeable acidity was extracted with $1 \mathrm{M} \mathrm{KCl}$ and quantified by titration. CEC was extracted using ammonium acetate method (van Reeuwijk 2002) in which the content was determined colorimetrically.

\section{Data analysis}

The soil data collected were subjected to statistical analysis of variance (ANOVA) using general linear mixed model (GLMM) in R statistical software version 3.4.2 ( $\mathrm{R}$ Core Team 2017). During the analysis, organic and mineral fertilizers were considered as fixed factor while site was considered as a random factor in the lme 4 package of $\mathrm{R}$ (Bates et al. 2015). The statistical model had the following general form (Eq. 1).

$$
T_{i j k}=\mu+S_{i}+O_{j}+M_{k}+(O M)_{j k}+\varepsilon_{i j k}
$$

where: $\mathrm{T}_{\mathrm{ijk}}$ is the total observation, $\mu$ is the overall mean, $S_{i}$ is the site effect, $O_{i}$ is the jth manure treatment effect, $M_{k}$ is kth NPK fertilizer treatment effect, $(O M)_{j k}$ is the interaction between manure and fertilizer, and $\varepsilon_{\mathrm{ijk}}$ is the variation due to random error.

This model was fitted to detect the main effect and two-way interaction between organic and mineral fertilizer over the three different sampling times separately. When the ANOVA showed significant difference, the means were separated using lsmeans package of $\mathrm{R}$ (Lenth 2016) with the Honestly Significant Difference (HSD) set at a $5 \%$ level of significance.

\section{Results}

\section{Initial soil fertility status and manure quality}

Table 1 presents results of soil analysis for the two research stations. In terms of physical properties, sandy texture dominates the soil particle size distribution (54-77\%), with low levels of silt (7-20\%) and clay (16-26\%) at Mansa and Kabangwe stations, respectively.
The sandy loam texture class at Mansa indicates alluvial and transported parent materials of the study site soils. The soil reaction of the two sites were 4.9 and 5.28 and the $\mathrm{pH}$ of manure was 7.48. Based on the rating according to (Hazelton and Murphy 2007), the soil reaction is rated very strongly acidic at Mansa and strongly acidic at Kabangwe, while the manure was slightly alkaline. In terms of nutrient supply capacity, the soils are very low in soil OC (1.0-1.2\%) and TN (0.05-0.06\%), and extremely low in CEC (3-4 $\left.\mathrm{cmol}^{+} \mathrm{kg}^{-1}\right)$ and basic cations $\left(\mathrm{Ca}^{2+}\right.$, $\mathrm{Mg}^{2+}, \mathrm{K}^{+}$and $\left.\mathrm{Na}^{+}\right)$. The soil at Kabangwe is particularly deficient in AP $\left(3.78 \mathrm{mg} \mathrm{kg}^{-1}\right)$ when that of Mansa has excess levels of AP $\left(20.51 \mathrm{mg} \mathrm{kg}^{-1}\right)$. This may indicate natural variation and/or difference in previous land use that has resulted in residual phosphate accumulation in Mansa and depletion at Kabangwe. The low levels of nutrients and CEC is consistent with the low levels of clay and therefore limited surface area for nutrient and cation retention as result of sandy nature of the soils (Brady and Weil 2002; Elias 2016). The implication of this is that application of organic fertilizers and leaf litter is essential to retain nutrients and enhance the soil organic matter content. In light of this, the chicken manure can contribute favorable qualities including high contents of OC (26\%) and organic matter (45\%), high levels of nutrients including TN $(3.6 \%)$ and CEC $\left(26 \mathrm{cmol}^{+} \mathrm{kg}^{-1}\right)$, cations such as $\mathrm{Ca}^{2+}\left(9 \mathrm{cmol}^{+} \mathrm{kg}^{-1}\right)$ and $\mathrm{K}^{+}\left(2 \mathrm{cmol}^{+}\right.$ $\mathrm{kg}^{-1}$ ), and most micronutrients ( $\mathrm{Fe}, \mathrm{Mn}, \mathrm{Zn}, \mathrm{Cu}$ ). The result therefore shows the potential of chicken manure as soil amendment to address the low levels of nutrients and organic matter in the soils. However, low levels of AP (1.3\%) and high levels of $\mathrm{Na}\left(8 \mathrm{cmol}^{+} \mathrm{kg}^{-1}\right)$ are the sources of concern suggesting the need for combining chicken manure with phosphate fertilizer to avoid salinity increases from large quantities of manure application.

\section{Effect of cassava fertilization on soil pH, organic carbon, total $\mathrm{N}$, and available $\mathrm{P}$}

Except for the mineral fertilizer at four MAP, soil reaction $(\mathrm{pH})$ was significantly $(p<0.05)$ affected by the application of both organic and mineral fertilizer. But no significant interaction effect was observed for soil $\mathrm{pH}$ across different cassava growth periods. Application of organic fertilizer on soil $\mathrm{pH}$ becomes more significant as time goes and it consistently and significantly improved $\mathrm{pH}$ level in the soil, especially at harvest (Table 2). On the other hand, the effect of mineral fertilizer application was significant from $8 \mathrm{MAP}$ and increased fertilizer application significantly reduced the soil $\mathrm{pH}$ level over the control. For plots treated by organic manure, the highest $\mathrm{pH}$ (5.94) was recorded for the plots that received 4.2 ton $\mathrm{ha}^{-1}$ manure at harvest while the lowest (5.22) was recorded from the control at 8 MAP. In 
Table 1 Selected physicochemical properties of topsoil (0-20 cm depth) of the two experimental sites and manure

\begin{tabular}{|c|c|c|c|c|}
\hline Parameters & Mansa & Kabangwe & Manure & Requirement $^{\mathbf{b}}$ \\
\hline \multicolumn{5}{|l|}{ Particle size (\%) } \\
\hline Sand & 77 & 54 & & \\
\hline Silt & 7 & 20 & & \\
\hline Clay & 16 & 26 & & \\
\hline Textural class & Sandy loam & Sandy clay loam & & \\
\hline $\mathrm{pH}$ (water) & 4.9 & 5.28 & 7.48 & 3.5-4.5 (in $\mathrm{H}_{2} \mathrm{O} 1: 1$ ) \\
\hline OC (\%) & 1.07 & 1.19 & 26 & 1-2 (Walkley and Black) \\
\hline TN (\%) & 0.05 & 0.06 & 3.6 & \\
\hline $\mathrm{C} / \mathrm{N}$ & 22.34 & 19.39 & 7.86 & \\
\hline $\mathrm{AP}\left(\mathrm{mg} \mathrm{kg}^{-1}\right)$ & 20.51 & 3.78 & $1.32^{\mathrm{a}}$ & $2-4$ \\
\hline $\mathrm{CEC}\left(\mathrm{cmol}^{+} \mathrm{kg}^{-1}\right)$ & 2.97 & 4.56 & 22.01 & \\
\hline \multicolumn{5}{|c|}{ Exchangeable bases $\left(\mathrm{cmol}^{+} \mathrm{kg}^{-1}\right)$} \\
\hline $\mathrm{Ca}$ & 1.22 & 2.57 & $8.6^{\mathrm{a}}$ & $0.25-1$ \\
\hline $\mathrm{Mg}$ & 0.29 & 1.2 & $0.62^{a}$ & $0.2-0.4$ \\
\hline K & 0.12 & 0.09 & $1.99^{\mathrm{a}}$ & $0.1-0.15$ \\
\hline $\mathrm{Na}$ & 0.044 & 0.045 & 7.75 & \\
\hline Total exchangeable bases & 1.674 & 3.905 & & \\
\hline \multicolumn{5}{|l|}{ Micronutrients $\left(\mathrm{mg} \mathrm{kg}^{-1}\right)$} \\
\hline $\mathrm{Zn}$ & 0.74 & 0.41 & 142.8 & $0.5-1$ \\
\hline $\mathrm{Cu}$ & 6.18 & 1.31 & 10.39 & $0.1-0.3$ \\
\hline $\mathrm{Mn}$ & 57 & 107 & 182 & $5-10$ \\
\hline $\mathrm{Fe}$ & 78 & 59 & 95 & $1-10$ \\
\hline
\end{tabular}

a Results are expressed in percent (\%)

b Low level cassava requirement as stated in Howeler (2014)

addition, $\mathrm{pH}$ reading was all high for the highest level of manure treatments across all the cassava growing periods with an increase of 9,10 , and $16.7 \%$ at 4,8 , and 12 MAP, respectively, compared to the control. For plots treated by mineral fertilizer, the highest mean $\mathrm{pH}$ (5.86) was recorded in the control plots at harvest while the lowest (5.32) was observed in the plots treated by 150-33$124.5 \mathrm{~kg} \mathrm{~N}-\mathrm{P}-\mathrm{K} \mathrm{kg} \mathrm{ha}^{-1}$ treatments at 8 MAP (Table 2). In general, increase in the application of mineral fertilizer resulted in lower soil $\mathrm{pH}$ across all the cassava growing periods. The highest level mineral fertilizer application resulted in $2.5,7.7$, and $7.5 \%$ reduction in soil $\mathrm{pH}$ level at 4,8 , and $12 \mathrm{MAP}$, respectively, compared to the control.

Except for the manure treatments at $8 \mathrm{MAP}$, soil OC was significantly (at least $p<0.05$ ) affected by both organic and mineral fertilizer application to cassava fields across all the growing periods. On the other hand, the effect of TN was pronounced at harvest time. At harvest, both organic and mineral fertilization significantly $(p<0.05)$ influenced soil TN level. With the only exception at 8 MAP that showed higher but statistically non-significant effect, manure application resulted in significantly lower OC and TN under the control plots; but consistently increased with the increased application of chicken manure. However, for soils treated by mineral fertilizers, the highest mean TN was recorded from the control and the least was recorded from the $M_{2}$ level of mineral fertilizer application during all the cassava growth period. While significant $O C$ variation was observed across all the cassava growth periods, the mineral treatment effect on soil TN was observed at the harvest stage. The highest mean OC level was again observed in the control plots for soils under mineral fertilizer, with $\mathrm{M}_{2}$ level application significantly reduced the soil OC during all the growth periods (Table 2).

At 4 MAP, the interaction effect between the organic and mineral fertilizer was marginally significant for $\mathrm{OC}$ and non-significant for TN. At 8 MAP, it significantly affected the soil OC content, but no significant effect was detected on TN levels. At harvest, both $\mathrm{OC}$ and TN levels were significantly $(p<0.05)$ affected by the interaction between chicken manure and NPK application. The mean OC content (1.4\%) was the highest at 4 and 12 MAP for the plots treated with $2.8 \mathrm{t}$ manure and 50-11-4.15 kg N-P-K ha ${ }^{-1}$ (treatments $\mathrm{O}_{1} \times \mathrm{M}_{1}$ ), and the lowest $(1.1 \%)$ was for plots received sole application of 150-33-124.5 kg N-P-K ha ${ }^{-1}\left(\mathrm{M}_{3}\right)$ at 12 MAP. On the other hand, highest level TN $(0.08 \%)$ was recorded for the 
Table 2 Cassava fertilization effect on pH (water), OC (\%), TN (\%) and AP $\left(\mathrm{mg} \mathrm{kg}^{-1}\right)$ over the three different sampling periods after planting at $a=0.05$

\begin{tabular}{|c|c|c|c|c|c|c|c|c|c|}
\hline \multicolumn{5}{|c|}{ Organic manure } & \multicolumn{5}{|c|}{ Mineral fertilizer } \\
\hline & $\mathrm{pH}$ & OC & TN & AP & & $\mathrm{pH}$ & OC & TN & AP \\
\hline \multicolumn{10}{|l|}{$4 M A P$} \\
\hline $\mathrm{O}_{0}$ & $5.27^{\mathrm{a}}$ & $1.13^{\mathrm{a}}$ & $0.058^{\mathrm{a}}$ & $36.63^{\mathrm{a}}$ & $M_{0}$ & $5.68^{\mathrm{a}}$ & $1.26^{b}$ & $0.066^{\mathrm{a}}$ & $43.07^{\mathrm{a}}$ \\
\hline $\mathrm{O}_{1}$ & $5.55^{\mathrm{ab}}$ & $1.28^{\mathrm{b}}$ & $0.066^{\mathrm{ab}}$ & $63.61^{\mathrm{ab}}$ & $M_{1}$ & $5.47^{\mathrm{a}}$ & $1.24^{\mathrm{ab}}$ & $0.067^{\mathrm{a}}$ & $58.24^{\mathrm{ab}}$ \\
\hline $\mathrm{O}_{2}$ & $5.60^{b}$ & $1.21^{\mathrm{ab}}$ & $0.066^{\mathrm{ab}}$ & $67.53^{\mathrm{ab}}$ & $\mathrm{M}_{2}$ & $5.50^{\mathrm{a}}$ & $1.15^{\mathrm{a}}$ & $0.061^{\mathrm{a}}$ & $71.04^{a b}$ \\
\hline $\mathrm{O}_{3}$ & $5.77^{b}$ & $1.23^{b}$ & $0.071^{b}$ & $101.96^{b}$ & $M_{3}$ & $5.54^{\mathrm{a}}$ & $1.20^{\mathrm{ab}}$ & $0.067^{\mathrm{a}}$ & $97.39^{b}$ \\
\hline F-value & 6.7156 & 8.3069 & 4.9478 & 5.3507 & & 1.2955 & 4.7104 & 1.6284 & 3.9428 \\
\hline$p$-value & 0.004 & 0.0017 & 0.0139 & 0.0105 & & 0.3123 & 0.0165 & 0.2249 & 0.0294 \\
\hline \multicolumn{10}{|l|}{$8 M A P$} \\
\hline $\mathrm{O}_{0}$ & $5.22^{\mathrm{a}}$ & $1.18^{\mathrm{a}}$ & $0.060^{\mathrm{a}}$ & $35.26^{\mathrm{a}}$ & $M_{0}$ & $5.73^{b}$ & $1.23^{b}$ & $0.067^{\mathrm{a}}$ & $47.34^{\mathrm{a}}$ \\
\hline $\mathrm{O}_{1}$ & $5.32^{\mathrm{ab}}$ & $1.20^{\mathrm{a}}$ & $0.064^{\mathrm{a}}$ & $50.96^{b}$ & $M_{1}$ & $5.42^{\mathrm{ab}}$ & $1.23^{b}$ & $0.063^{\mathrm{a}}$ & $66.67^{b c}$ \\
\hline $\mathrm{O}_{2}$ & $5.57^{\mathrm{bc}}$ & $1.21^{\mathrm{a}}$ & $0.067^{\mathrm{a}}$ & $72.12^{c}$ & $\mathrm{M}_{2}$ & $5.38^{\mathrm{a}}$ & $1.15^{\mathrm{a}}$ & $0.061^{\mathrm{a}}$ & $59.39^{\mathrm{ab}}$ \\
\hline $\mathrm{O}_{3}$ & $5.75^{c}$ & $1.23^{\mathrm{a}}$ & $0.067^{\mathrm{a}}$ & $90.00^{d}$ & $\mathrm{M}_{3}$ & $5.32^{\mathrm{a}}$ & $1.21^{\mathrm{ab}}$ & $0.066^{\mathrm{a}}$ & $74.93^{c}$ \\
\hline F-value & 7.9466 & 1.2766 & 2.7402 & 47.700 & & 4.6928 & 4.1016 & 1.8743 & 11.369 \\
\hline$p$-value & 0.002 & 0.3183 & 0.0799 & $<0.001$ & & 0.016 & 0.026 & 0.1773 & $<0.001$ \\
\hline \multicolumn{10}{|l|}{$12 \mathrm{MAP}$} \\
\hline $\mathrm{O}_{0}$ & $5.09^{a}$ & $1.14^{\mathrm{a}}$ & $0.061^{\mathrm{a}}$ & $42.49^{a}$ & $M_{0}$ & $5.86^{b}$ & $1.28^{c}$ & $0.074^{b}$ & $69.97^{a}$ \\
\hline $\mathrm{O}_{1}$ & $5.41^{\mathrm{b}}$ & $1.25^{\mathrm{b}}$ & $0.070^{b}$ & $65.36^{\mathrm{a}}$ & $M_{1}$ & $5.41^{\mathrm{a}}$ & $1.25^{b c}$ & $0.072^{\mathrm{ab}}$ & $92.52^{\mathrm{a}}$ \\
\hline $\mathrm{O}_{2}$ & $5.71^{c}$ & $1.21^{\mathrm{ab}}$ & $0.074^{b c}$ & $107.77^{b}$ & $\mathrm{M}_{2}$ & $5.43^{\mathrm{a}}$ & $1.15^{\mathrm{a}}$ & $0.068^{\mathrm{a}}$ & $85.33^{a}$ \\
\hline $\mathrm{O}_{3}$ & $5.94^{d}$ & $1.25^{\mathrm{b}}$ & $0.077^{c}$ & $155.79^{c}$ & $\mathrm{M}_{3}$ & $5.45^{\mathrm{a}}$ & $1.17^{\mathrm{ab}}$ & $0.069^{\mathrm{a}}$ & $123.59^{b}$ \\
\hline$F$-value & 42.891 & 7.3924 & 32.26 & 46.829 & & 14.276 & 9.8746 & 5.067 & 9.555 \\
\hline$p$-value & $<0.001$ & 0.0029 & $<0.001$ & $<0.001$ & & $<0.001$ & $<0.001$ & 0.0127 & $<0.001$ \\
\hline
\end{tabular}

Means in the same column with the same letter are not significantly different. $M A P$ months after planting. $\mathrm{O}_{0}=$ control (without manure application), $\mathrm{O}_{1}=1.4 \mathrm{t}$ ha ${ }^{-1}$ chicken manure, $\mathrm{O}_{2}=2.8 \mathrm{t} \mathrm{ha}^{-1}$ chicken manure, $\mathrm{O}_{3}=4.2 \mathrm{t} \mathrm{ha}^{-1}$ chicken manure, $\mathrm{M}_{0}=$ control (without mineral fertilizer), $\mathrm{M}_{1}=50 \mathrm{~N}-11 \mathrm{P}-41.5 \mathrm{~K} \mathrm{~kg}$ ha ${ }^{-1}, \mathrm{M}_{2}=100 \mathrm{~N}-$ $22 \mathrm{P}-83 \mathrm{~K} \mathrm{~kg} \mathrm{ha}^{-1}, \mathrm{M}_{3}=150 \mathrm{~N}-33 \mathrm{P}-123.5 \mathrm{~K} \mathrm{~kg} \mathrm{ha}^{-1}$

sole application of $4.2 \mathrm{t}$ chicken manure ha ${ }^{-1}\left(\mathrm{O}_{3} \times \mathrm{M}_{0}\right)$ at 12 MAP (Fig. 2).

Application of both organic and mineral fertilizer consistently and significantly $(p<0.05)$ increased AP with no significant interaction effect between them (Table 2). The mean AP was lower in the control and higher in the highest levels of both the manure and mineral fertilizer treatments across the different growth periods. Mean AP was the least in the control plot $\left(35.26 \mathrm{mg} \mathrm{kg}^{-1}\right)$ at $8 \mathrm{MAP}$, compared to the highest $\left(155.8 \mathrm{mg} \mathrm{kg}^{-1}\right)$ at harvest in the plots treated with 4.2 ton $\mathrm{ha}^{-1}$ chicken manure. On the other hand, for the plots treated by mineral fertilizer, the least AP was observed in the control plots $\left(43.1 \mathrm{mg} \mathrm{kg}^{-1}\right)$ at $4 \mathrm{MAP}$ while it was the highest $\left(123.6 \mathrm{mg} \mathrm{kg}^{-1}\right)$ in $\mathrm{M}_{3}$ plots at harvest (Table 2).

\section{Effect of cassava fertilization on exchangeable bases $\left(\mathrm{Ca}^{2+}\right.$, $\mathrm{Mg}^{2+}, \mathrm{K}^{+}, \mathrm{Na}^{+}$) and CEC}

Exchangeable bases under the cassava plots were significantly $(p<0.05)$ affected by the application of organic fertilizer, with the exception of soil $\mathrm{K}^{+}$level that was marginally significant only at 8 MAP. There was no effect of mineral fertilizer application on exchangeable bases at 4
MAP, except $\mathrm{K}^{+}$. But mineral fertilizer application significantly affected the level of soil exchangeable bases at 8 and $12 \mathrm{MAP}$, except $\mathrm{Na}^{+}$. No significant interaction effect was observed between organic and mineral fertilizer application on soil exchangeable bases. The application of organic and mineral fertilizers, and their interaction significantly $(p<0.05)$ affected CEC-soil during all the cassava growth periods (Table 3 ).

Application of organic fertilizer consistently increased all the exchangeable bases over the control plots. The increased relation was statistically significant in plots that received $4.2 \mathrm{t}$ manure $\mathrm{ha}^{-1}$ and at harvest (Table 3). The highest level $\left(5.43,1.28,0.69\right.$, and $\left.0.05 \mathrm{mg} \mathrm{kg}^{-1}\right)$ of exchangeable bases: $\mathrm{Ca}^{2+}, \mathrm{Mg}^{2+}, \mathrm{K}^{+}$, and $\mathrm{Na}^{+}$, respectively were recorded from $\mathrm{O}_{3}$ treatments, all at 12 MAP. However, the least $\mathrm{Ca}^{2+}\left(2.01 \mathrm{mg} \mathrm{kg}^{-1}\right)$-at $8 \mathrm{MAP}, \mathrm{Mg}^{2+}$ $\left(0.85 \mathrm{mg} \mathrm{kg}^{-1}\right)$ - at 4 and $8 \mathrm{MAP}^{+} \mathrm{K}^{+}\left(0.34 \mathrm{mg} \mathrm{kg}^{-1}\right)$ at $8 \mathrm{MAP}$, and $\mathrm{Na}^{+}\left(0.01 \mathrm{mg} \mathrm{kg}^{-1}\right)$-at $4 \mathrm{MAP}$ were all recorded from the treatments without organic fertilizer (controls). While mean $\mathrm{Ca}^{2+}$ and $\mathrm{Mg}^{2+}$ content in the soil were the highest in the control plots, they were the least for $\mathrm{K}^{+}$and $\mathrm{Na}^{+}$for soils treated by mineral fertilizer application. To be more specific, mineral fertilizer 


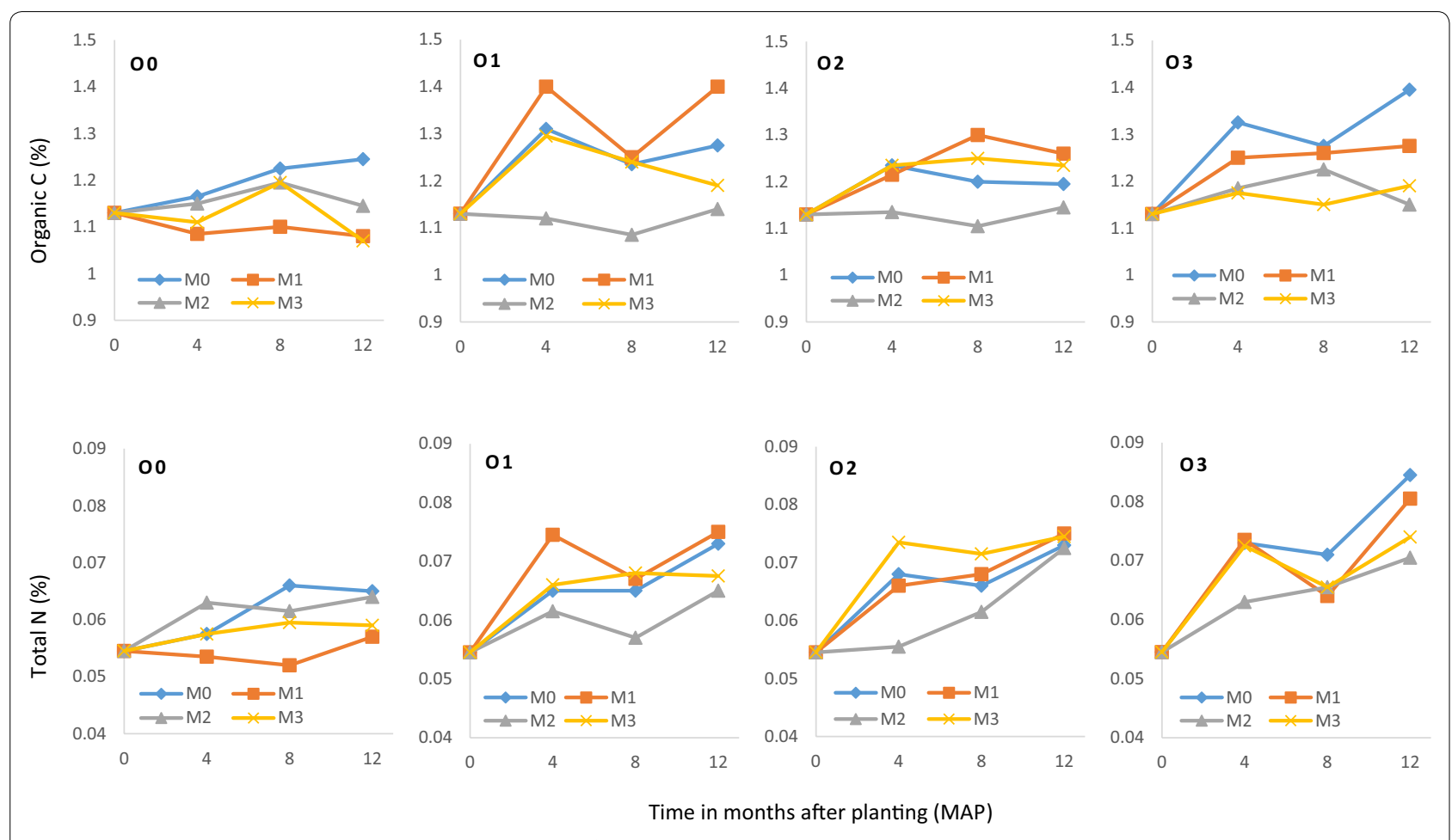

Fig. 2 The interaction effect between organic and mineral fertilizer on organic carbon and total nitrogen

application significantly decreased $\mathrm{Ca}^{2+}$ and $\mathrm{Mg}^{2+}$ contents, especially at 8 and 12 MAP. While $\mathrm{K}^{+}$significantly increased, the increase in exchangeable $\mathrm{Na}^{+}$content was not statistically significant across all the growing periods under cassava fields in Zambia (Table 3).

Cation exchange capacity (CEC) of the soil, on the other hand, significantly affected by organic, mineral fertilization and their interaction, with the only exception of manure application at 8 MAP. While CEC was significantly lower in the control, it was higher in plots treated by organic amendments with no significant variation between the different levels. However, it was significantly higher in the control plots at 4 MAP, significantly higher in the control compared to $\mathrm{M}_{2}$ at 8 and $12 \mathrm{MAP}$, and no significant difference between $M_{1}$ and $M_{3}$ levels for soils amended by mineral fertilizer. For the combined application, mean CEC was the least $\left(2.96 \mathrm{cmol}^{+} \mathrm{kg}^{-1}\right)$ under the plots treated by $\mathrm{O}_{0} \times \mathrm{M}_{1}$ at harvest while it was the highest $\left(4.36 \mathrm{cmol}^{+} \mathrm{kg}^{-1}\right)$ for plots treated by $\mathrm{O}_{2} \times \mathrm{M}_{0}$ at 4 MAP (Fig. 3).

Effect of cassava fertilization on micronutrients (Fe, Mn, Zn, Cu)

The application of organic fertilizer either marginally or significantly $(p<0.05)$ affected soil $\mathrm{Zn}$ and Mn content, but no significant effect on $\mathrm{Cu}$ and Fe was observed. The application of mineral fertilizer however, significantly $(p<0.05)$ influenced soil $\mathrm{Cu}$ and Mn content at 4 MAP, $\mathrm{Mn}$ and Fe content at $8 \mathrm{MAP}$ and all micronutrients except $\mathrm{Zn}$ at harvest. Application of chicken manure consistently and significantly improved $\mathrm{Zn}$ content throughout the cassava growth period. However, Zn content was the lowest in plots that received 100-22$83 \mathrm{~kg} \mathrm{~N}-\mathrm{P}-\mathrm{K} \mathrm{ha}^{-1}$ during all the cassava growing periods, the lowest being at 8 MAP (Table 4). In addition, organic fertilizer application improved soil $\mathrm{Cu}$ content with no significant difference observed between plots treated by different levels of organic fertilizer and the control at the different growth stages. However, application of mineral fertilizer significantly reduced soil $\mathrm{Cu}$ content with the highest mean $\mathrm{Cu}$ content observed in the control plots compared to $\mathrm{M}_{3}$ at $4 \mathrm{MAP} ; \mathrm{M} 2$ and M3 at 12 MAP. Though the $\mathrm{Cu}$ level consistently declined with the application of more mineral fertilizer, no significant difference was observed between the different levels at 8 MAP. On the other hand, an increase in the application of manure consistently increased soil $\mathrm{Mn}$ content across all the growing season. But, the increase was statistically significant only at 4 MAP. At this stage of the cassava growth, $\mathrm{O}_{3}$ level of manure resulted in significantly highest $\left(114.7 \mathrm{mg} \mathrm{kg}^{-1}\right) \mathrm{Mn}$ content compared to the control plots, but no significant difference was observed with the other manure levels (Table 4). Application of mineral fertilizer resulted in significantly 
Table 3 Cassava fertilization effect on CEC, and exchangeable bases $\left(\mathrm{cmol}^{+} \mathbf{~ k g}^{-1}\right.$ ) at different sampling periods

\begin{tabular}{|c|c|c|c|c|c|c|c|c|c|c|c|}
\hline \multicolumn{6}{|c|}{ Organic manure } & \multicolumn{6}{|c|}{ Mineral fertilizer } \\
\hline & CEC & $\mathrm{Ca}^{2+}$ & $\mathrm{Mg}^{2+}$ & $\mathrm{Na}^{+}$ & $\mathrm{K}^{+}$ & & CEC & $\mathrm{Ca}^{2+}$ & $\mathrm{Mg}^{2+}$ & $\mathrm{Na}^{+}$ & $\mathrm{K}^{+}$ \\
\hline \multicolumn{12}{|l|}{$4 M A P$} \\
\hline $\mathrm{O}_{0}$ & $3.67^{\mathrm{a}}$ & $2.38^{\mathrm{a}}$ & $0.85^{\mathrm{a}}$ & $0.01^{\mathrm{a}}$ & $0.42^{\mathrm{a}}$ & $M_{0}$ & $4.27^{b}$ & $3.47^{\mathrm{a}}$ & $1.03^{\mathrm{a}}$ & $0.02^{\mathrm{a}}$ & $0.24^{\mathrm{a}}$ \\
\hline $\mathrm{O}_{1}$ & $4.01^{b}$ & $3.16^{a b}$ & $0.91^{\mathrm{a}}$ & $0.02^{\mathrm{ab}}$ & $0.53^{\mathrm{a}}$ & $M_{1}$ & $3.71^{\mathrm{a}}$ & $3.26^{\mathrm{a}}$ & $0.98^{\mathrm{a}}$ & $0.02^{\mathrm{a}}$ & $0.41^{\mathrm{a}}$ \\
\hline $\mathrm{O}_{2}$ & $3.90^{\mathrm{ab}}$ & $3.43^{b c}$ & $1.00^{\mathrm{ab}}$ & $0.03^{\mathrm{ab}}$ & $0.49^{\mathrm{a}}$ & $M_{2}$ & $3.67^{\mathrm{a}}$ & $3.07^{\mathrm{a}}$ & $0.94^{\mathrm{a}}$ & $0.03^{\mathrm{a}}$ & $0.57^{\mathrm{ab}}$ \\
\hline $\mathrm{O}_{3}$ & $3.88^{\mathrm{ab}}$ & $4.09^{c}$ & $1.12^{b}$ & $0.04^{b}$ & $0.62^{\mathrm{a}}$ & $M_{3}$ & $3.81^{\mathrm{a}}$ & $3.25^{\mathrm{a}}$ & $0.92^{\mathrm{a}}$ & $0.03^{\mathrm{a}}$ & $0.84^{b}$ \\
\hline F-value & 2.9957 & 10.15 & 7.0216 & 4.0067 & 0.8062 & & 11.9162 & 0.5511 & 1.1580 & 0.072 & 7.7144 \\
\hline$p$-value & 0.064 & $<0.001$ & 0.004 & 0.028 & 0.5098 & & $<0.001$ & 0.6551 & 0.3583 & 0.974 & 0.0024 \\
\hline \multicolumn{12}{|l|}{$8 M A P$} \\
\hline $\mathrm{O}_{0}$ & $3.69^{\mathrm{a}}$ & $2.01^{\mathrm{a}}$ & $0.85^{\mathrm{a}}$ & $0.012^{\mathrm{a}}$ & $0.34^{\mathrm{a}}$ & $M_{0}$ & $4.05^{b}$ & $3.09^{b}$ & $1.07^{b}$ & $0.018^{a}$ & $0.18^{\mathrm{a}}$ \\
\hline $\mathrm{O}_{1}$ & $3.95^{\mathrm{a}}$ & $2.66^{b}$ & $0.87^{a b}$ & $0.017^{\mathrm{ab}}$ & $0.39^{\mathrm{a}}$ & $M_{1}$ & $3.90^{\mathrm{ab}}$ & $3.03^{\mathrm{ab}}$ & $0.97^{\mathrm{ab}}$ & $0.019^{a}$ & $0.37^{b}$ \\
\hline $\mathrm{O}_{2}$ & $3.85^{\mathrm{a}}$ & $3.19^{b c}$ & $1.02^{b}$ & $0.022^{\mathrm{ab}}$ & $0.44^{\mathrm{a}}$ & $M_{2}$ & $3.62^{\mathrm{a}}$ & $2.50^{\mathrm{a}}$ & $0.84^{\mathrm{a}}$ & $0.021^{a}$ & $0.43^{b}$ \\
\hline $\mathrm{O}_{3}$ & $3.87^{\mathrm{a}}$ & $3.60^{c}$ & $1.02^{b}$ & $0.029^{b}$ & $0.46^{\mathrm{a}}$ & $M_{3}$ & $3.79^{a b}$ & $2.84^{\mathrm{ab}}$ & $0.87^{\mathrm{a}}$ & $0.022^{\mathrm{a}}$ & $0.65^{c}$ \\
\hline F-value & 2.0541 & 25.3393 & 5.3156 & 5.9708 & 2.942 & & 5.7742 & 3.7821 & 7.2504 & 0.3535 & 40.253 \\
\hline$p$-value & 0.1494 & $<0.001$ & 0.0107 & 0.0069 & 0.067 & & 0.0079 & 0.033 & 0.0031 & 0.7873 & $<0.001$ \\
\hline \multicolumn{12}{|l|}{$12 M A P$} \\
\hline $\mathrm{O}_{0}$ & $3.38^{\mathrm{a}}$ & $2.41^{\mathrm{a}}$ & $0.93^{\mathrm{a}}$ & $0.026^{\mathrm{a}}$ & $0.55^{\mathrm{a}}$ & $M_{0}$ & $3.81^{b}$ & $4.24^{b}$ & $1.34^{b}$ & $0.032^{\mathrm{a}}$ & $0.23^{\mathrm{a}}$ \\
\hline $\mathrm{O}_{1}$ & $3.76^{b}$ & $3.52^{b}$ & $1.04^{\mathrm{ab}}$ & $0.033^{\mathrm{ab}}$ & $0.59^{\mathrm{a}}$ & $M_{1}$ & $3.67^{b}$ & $3.94^{\mathrm{ab}}$ & $1.10^{\mathrm{ab}}$ & $0.038^{\mathrm{a}}$ & $0.54^{b}$ \\
\hline $\mathrm{O}_{2}$ & $3.67^{b}$ & $4.15^{c}$ & $1.18^{\mathrm{ab}}$ & $0.039^{b c}$ & $0.62^{\mathrm{a}}$ & $M_{2}$ & $3.36^{\mathrm{a}}$ & $3.58^{a}$ & $1.00^{\mathrm{a}}$ & $0.038^{a}$ & $0.70^{b c}$ \\
\hline $\mathrm{O}_{3}$ & $3.69^{b}$ & $5.43^{d}$ & $1.28^{b}$ & $0.048^{c}$ & $0.69^{\mathrm{a}}$ & $M_{3}$ & $3.65^{b}$ & $3.77^{\mathrm{ab}}$ & $0.99^{\mathrm{a}}$ & $0.040^{\mathrm{a}}$ & $0.97^{c}$ \\
\hline$F$-value & 9.1877 & 90.315 & 4.4782 & 9.4235 & 0.7512 & & 11.7613 & 4.514 & 5.0395 & 1.0404 & 20.2483 \\
\hline$p$-value & 0.001 & $<0.001$ & 0.0195 & $<0.001$ & 0.5385 & & $<0.001$ & 0.019 & 0.013 & 0.4031 & $<0.001$ \\
\hline
\end{tabular}

Means in the same column with the same letter are not significantly different. $M A P$ months after planting. $\mathrm{O}_{0}=$ control (without manure application), $\mathrm{O}_{1}=1.4 \mathrm{t} \mathrm{ha}{ }^{-1}$ chicken manure, $\mathrm{O}_{2}=2.8 \mathrm{tha}^{-1}$ chicken manure, $\mathrm{O}_{3}=4.2 \mathrm{tha}^{-1}$ chicken manure, $\mathrm{M}_{0}=$ control (without mineral fertilizer), $\mathrm{M}_{1=}=50 \mathrm{~N}-11 \mathrm{P}-41.5 \mathrm{~K}$ kg ha ${ }^{-1}, \mathrm{M}_{2}=100 \mathrm{~N}-$ $22 \mathrm{P}-83 \mathrm{~K} \mathrm{~kg} \mathrm{ha}^{-1}, \mathrm{M}_{3}=150 \mathrm{~N}-33 \mathrm{P}-123.5 \mathrm{~K} \mathrm{~kg} \mathrm{ha}^{-1}$

lower Mn content in the control plots compared to those plots that received the different levels of fertilizer treatments. However, no significant variation was observed among the other levels of mineral fertilizer. On the other hand, the application of organic fertilizer improved soil Fe content during all the growth periods. But, no significant difference was observed between the different manure levels and the control. Conversely, starting from 8 MAP, the application of mineral fertilizer significantly improved soil Fe content compared to the control, but no significant variation was observed between the different fertilizer levels.

The interaction effect of organic and mineral fertilizer was only marginally significant for Fe at $12 \mathrm{MAP}$ and significant $(p<0.05)$ for Mn at 4 and 12 MAP. The highest $\left(142.5 \mathrm{mg} \mathrm{kg}^{-1}\right)$ mean $\mathrm{Mn}$ level in the soil was recorded by the combined application of $\mathrm{O}_{1} \times \mathrm{M}_{2}$ at harvest while the lowest was from plots treated by $\mathrm{O}_{1} \times \mathrm{M} 0$ at $8 \mathrm{MAP}$. The highest soil Fe level $\left(101 \mathrm{mg} \mathrm{kg}^{-1}\right)$ was observed in the plots treated with $\mathrm{O}_{3} \times \mathrm{M}_{1}$ at harvest while the lowest mean $\left(66.5 \mathrm{mg} \mathrm{kg}^{-1}\right)$ was observed from the plots treated with $\mathrm{O}_{2} \times \mathrm{M}_{1}$ at 8 MAP (Fig. 4).

\section{Discussion}

The intensification effort of crop-based agriculture in every corner of the world has been followed by an increase in the use of chemical fertilizer (Morris et al. 2007). However, the consequence of this fertilizer use must be understood to take corrective measure for the sustainable production of crops in Africa in general and in Zambia in particular. In this research the use of organic fertilizer increased $\mathrm{pH}$ level in the soil, while the opposite happened with the use of mineral fertilizer application to cassava fields. Different outcomes were reported by different researchers regarding the application of fertilizer on cassava fields. For example, Makinde and Agboola (2002) reported a decline in soil $\mathrm{pH}$ level when cassava was fertilized either by organic or by mineral fertilizer. However, others reported the use of organic fertilizer (chicken manure) significantly increased soil $\mathrm{pH}$ level of cassava fields but the use of mineral fertilizer decreased it (Bodruzzaman 2010; Rós et al. 2013). The increase in soil $\mathrm{pH}$ following the application of organic fertilizer was attributed to different causes such as oxidation of organic acids, ammonification of $\mathrm{N}$, reduction reactions created by anaerobiosis, and adsorption of organic 

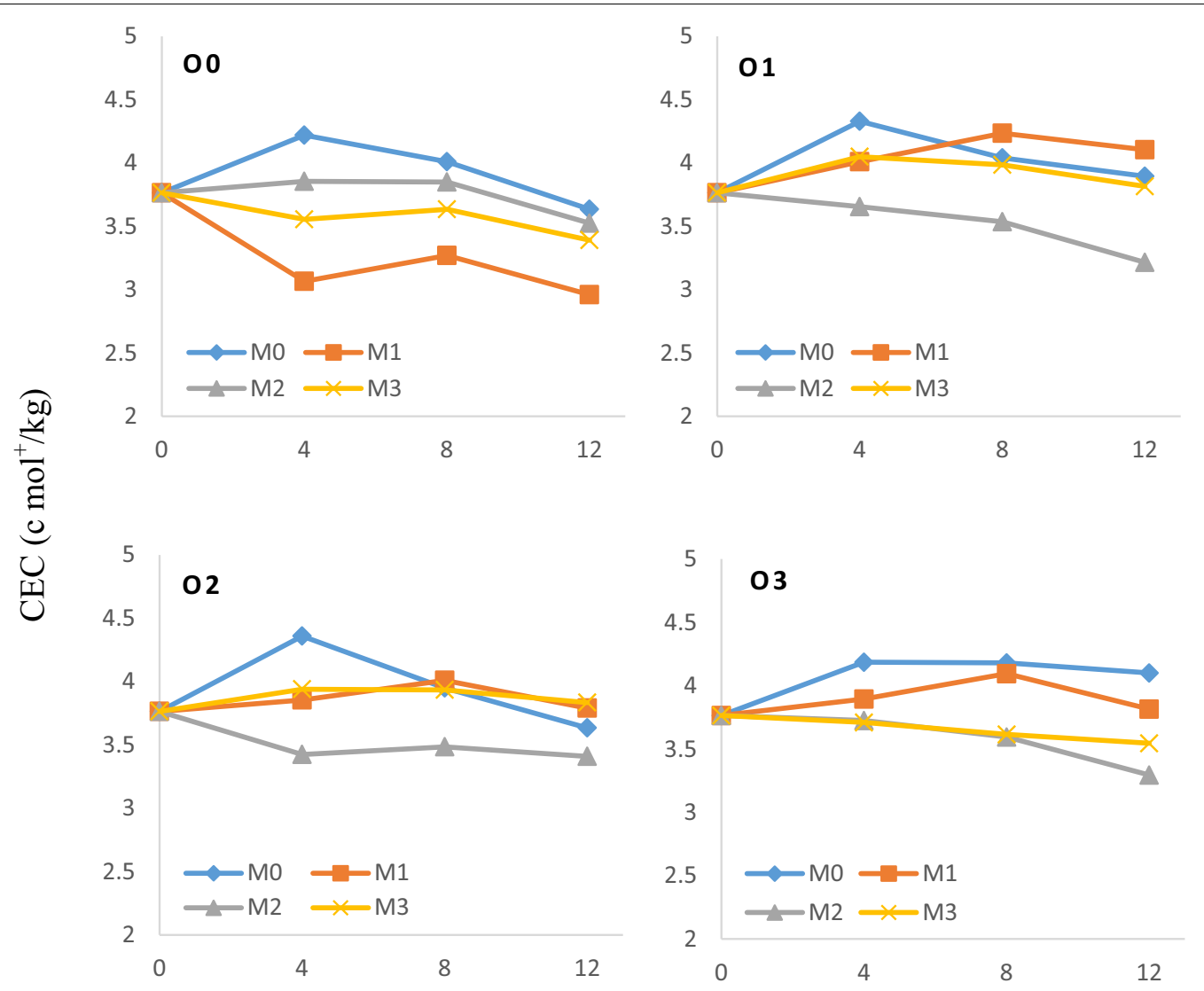

Time in months after planting

Fig. 3 The interaction effect between organic and mineral fertilizer on soil CEC

molecules during the decomposition of organic fertilizer (Haynes and Mokolobate 2001). Though most crops grow between 5.5 to $6.5 \mathrm{pH}$, reduction below this level of soil $\mathrm{pH}$ as a result of mineral fertilizer application is not a problem for cassava growers, because cassava belongs to the most tolerant crops to low $\mathrm{pH}$ level in the soil (Islam et al. 1980).

The application of organic, mineral fertilizer and their interaction also resulted in significant variation in soil $\mathrm{TN}$ and OC. While both nutrients increased following the application of organic manure, they declined with the application of mineral fertilizer. The increase in the soil TN and OC following the fertilization of cassava with organic fertilizer was reported earlier (Amanullah et al. 2007; Howeler 2001) and our finding also corroborate with these previous results. The increase in $\mathrm{TN}$ and $\mathrm{OC}$ was because of the triple effect of organic matter from the organic fertilizers: net source of carbon and nutrients, increase in cation exchange capacity and stimulation of the biological communities in the soil (Salami and Sangoyomi 2013). Of course, the quality of the organic material, mainly the $\mathrm{C}: \mathrm{N}$, matters for these to happen since high $\mathrm{C}: \mathrm{N}$ ratio (roughly $\geq 30 / 1$ ) can result in immobilization of $\mathrm{N}$ that can last from short to longer period, depending on the temperature of the area and the moisture content of the soil (Bakayoko et al. 2009). In our case, the chicken manure we used has low C:N (7.86) that is not a problem in this regard. However, care has to be given to the amount of manure applied as it depends on the manure quality, nutrient availability in the soil, the crop demand and the environmental conditions (Eghball et al. 2002). Fifty to hundred percent productivity increment is expected from the use of mineral fertilizer (Chianu et al. 2012) and about half the biomass of matured cassava plant is its roots (Hauser et al. 2014). Cassava is known as heavy feeder that can remove significant amount of plant nutrients with the root harvest (Osundare 2014). Contrary to animal manure that contain variable nutrient contents (Howeler 2001), which can provide plant nutrients gradually for several years (Eghball et al. 2002), mineral fertilizers contain fixed amount of nutrients that can be released within short period of time. 
Table 4 Cassava fertilization effect on $\mathrm{Cu}, \mathrm{Mn}, \mathrm{Fe}$, and $\mathrm{Zn}$ (all in $\mathrm{mg} \mathrm{kg}^{-1}$ ) over the three different sampling periods after planting at $a=0.05$

\begin{tabular}{|c|c|c|c|c|c|c|c|c|c|}
\hline \multicolumn{5}{|c|}{ Organic manure } & \multicolumn{5}{|c|}{ Mineral fertilizer } \\
\hline & $\mathrm{Cu}$ & $M n$ & $\mathrm{Fe}$ & $\mathrm{Zn}$ & & $\mathrm{Cu}$ & $M n$ & $\mathrm{Fe}$ & $\mathrm{Zn}$ \\
\hline \multicolumn{10}{|l|}{$4 M A P$} \\
\hline $\mathrm{O}_{0}$ & $3.38^{\mathrm{a}}$ & $103.02^{\mathrm{a}}$ & $76.38^{\mathrm{a}}$ & $1.40^{\mathrm{a}}$ & $M_{0}$ & $6.58^{b}$ & $97.81^{\mathrm{a}}$ & $76.50^{\mathrm{a}}$ & $2.11^{\mathrm{a}}$ \\
\hline $\mathrm{O}_{1}$ & $3.72^{\mathrm{a}}$ & $104.73^{\mathrm{ab}}$ & $82.13^{\mathrm{a}}$ & $1.87^{\mathrm{a}}$ & $M_{1}$ & $2.73^{a b}$ & $109.41^{b}$ & $79.00^{\mathrm{a}}$ & $2.24^{\mathrm{a}}$ \\
\hline $\mathrm{O}_{2}$ & $2.41^{\mathrm{a}}$ & $110.46^{\mathrm{ab}}$ & $78.75^{\mathrm{a}}$ & $2.19^{\mathrm{ab}}$ & $\mathrm{M}_{2}$ & $2.03^{\mathrm{ab}}$ & $115.13^{b}$ & $81.00^{\mathrm{a}}$ & $2.05^{\mathrm{a}}$ \\
\hline $\mathrm{O}_{3}$ & $3.90^{\mathrm{a}}$ & $114.70^{b}$ & $79.88^{\mathrm{a}}$ & $3.12^{\mathrm{b}}$ & $M_{3}$ & $2.06^{\mathrm{a}}$ & $111.09^{b}$ & $80.63^{a}$ & $2.18^{\mathrm{a}}$ \\
\hline F-value & 0.7295 & 4.1885 & 1.1866 & 8.5705 & & 4.1381 & 8.513 & 0.8691 & 0.1114 \\
\hline$p$-value & 0.5502 & 0.0243 & 0.3482 & 0.0015 & & 0.0253 & 0.0015 & 0.4788 & 0.9521 \\
\hline \multicolumn{10}{|l|}{$8 M A P$} \\
\hline $\mathrm{O}_{0}$ & $3.24^{\mathrm{a}}$ & $101.75^{\mathrm{a}}$ & $73.50^{\mathrm{a}}$ & $0.64^{\mathrm{a}}$ & $M_{0}$ & $6.12^{\mathrm{a}}$ & $98.63^{\mathrm{a}}$ & $68.37^{\mathrm{a}}$ & $1.40^{\mathrm{b}}$ \\
\hline $\mathrm{O}_{1}$ & $4.25^{\mathrm{a}}$ & $103.50^{\mathrm{a}}$ & $76.50^{\mathrm{a}}$ & $1.02^{\mathrm{b}}$ & $M_{1}$ & $3.02^{\mathrm{a}}$ & $107.13^{\mathrm{ab}}$ & $75.75^{b}$ & $1.38^{\mathrm{b}}$ \\
\hline $\mathrm{O}_{2}$ & $2.86^{\mathrm{a}}$ & $109.38^{\mathrm{a}}$ & $77.00^{\mathrm{a}}$ & $1.50^{c}$ & $\mathrm{M}_{2}$ & $2.74^{\mathrm{a}}$ & $106.50^{\mathrm{ab}}$ & $77.50^{\mathrm{b}}$ & $1.02^{\mathrm{a}}$ \\
\hline $\mathrm{O}_{3}$ & $3.94^{\mathrm{a}}$ & $109.88^{a}$ & $76.38^{a}$ & $1.94^{d}$ & $M_{3}$ & $2.40^{\mathrm{a}}$ & $112.25^{b}$ & $81.75^{b}$ & $1.30^{\mathrm{ab}}$ \\
\hline F-value & 0.3218 & 2.6491 & 0.8652 & 42.554 & & 2.3654 & 4.9632 & 10.7156 & 4.038 \\
\hline$p$-value & 0.8095 & 0.0866 & 0.4806 & $<0.001$ & & 0.112 & 0.0137 & $<0.001$ & 0.0257 \\
\hline \multicolumn{10}{|l|}{$12 M A P$} \\
\hline $\mathrm{O}_{0}$ & $2.76^{\mathrm{a}}$ & $128.63^{a}$ & $89.00^{\mathrm{a}}$ & $0.69^{\mathrm{a}}$ & $M_{0}$ & $6.41^{c}$ & $118.38^{\mathrm{a}}$ & $86.88^{a}$ & $1.94^{\mathrm{a}}$ \\
\hline $\mathrm{O}_{1}$ & $3.92^{\mathrm{a}}$ & $127.00^{\mathrm{a}}$ & $92.00^{\mathrm{a}}$ & $1.43^{b}$ & $M_{1}$ & $2.91^{b c}$ & $136.13^{b}$ & $95.75^{b}$ & $1.93^{\mathrm{a}}$ \\
\hline $\mathrm{O}_{2}$ & $2.55^{\mathrm{a}}$ & $135.13^{\mathrm{a}}$ & $92.88^{\mathrm{a}}$ & $2.15^{c}$ & $\mathrm{M}_{2}$ & $1.78^{\mathrm{a}}$ & $135.63^{b}$ & $91.25^{\mathrm{ab}}$ & $1.76^{\mathrm{a}}$ \\
\hline $\mathrm{O}_{3}$ & $4.06^{a}$ & $133.75^{\mathrm{a}}$ & $94.63^{\mathrm{a}}$ & $3.54^{d}$ & $M_{3}$ & $2.18^{a b}$ & $134.38^{b}$ & $94.63^{b}$ & $2.18^{\mathrm{a}}$ \\
\hline$F$-value & 2.1305 & 2.492 & 2.3137 & 78.18 & & 11.9745 & 11.7901 & 6.6536 & 1.589 \\
\hline$p$-value & 0.1391 & 0.0997 & 0.1174 & $<0.001$ & & $<0.001$ & $<0.001$ & 0.0045 & 0.2336 \\
\hline
\end{tabular}

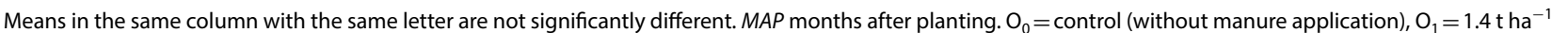
chicken manure, $\mathrm{O}_{2}=2.8 \mathrm{t} \mathrm{ha}^{-1}$ chicken manure, $\mathrm{O}_{3}=4.2 \mathrm{t} \mathrm{ha}^{-1}$ chicken manure, $\mathrm{M}_{0}=$ control (without mineral fertilizer), $\mathrm{M}_{1}=50 \mathrm{~N}-11 \mathrm{P}-41.5 \mathrm{~K} \mathrm{~kg}$ ha ${ }^{-1}, \mathrm{M}_{2}=100 \mathrm{~N}-$ $22 \mathrm{P}-83 \mathrm{~K} \mathrm{~kg} \mathrm{ha}^{-1}, \mathrm{M}_{3}=150 \mathrm{~N}-33 \mathrm{P}-123.5 \mathrm{~K} \mathrm{~kg} \mathrm{ha}^{-1}$

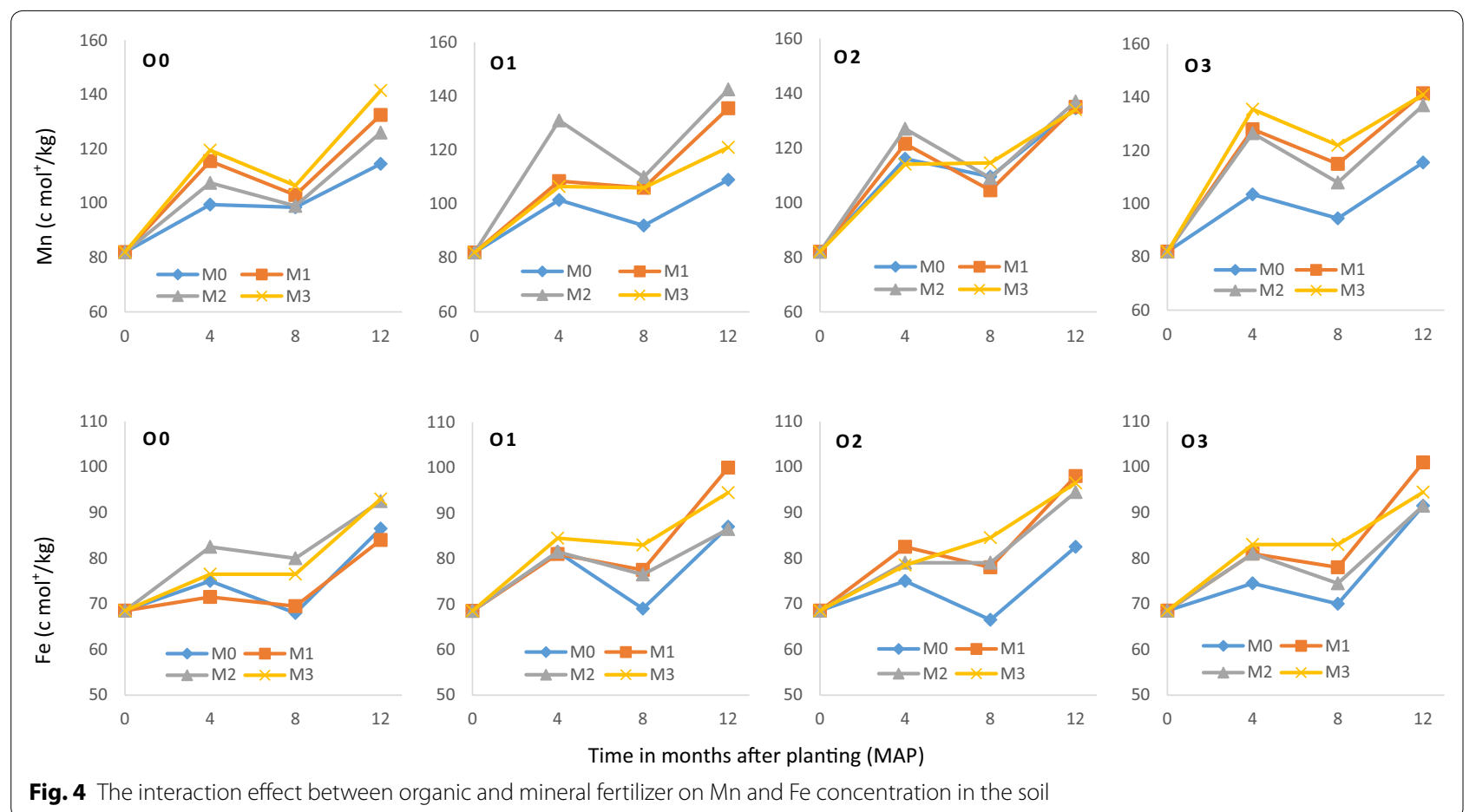


Because it is readily available, it can easily be up taken by the plant, volatile or leached. This may be the reason why mineral fertilizer application resulted in low level of $\mathrm{TN}$ in the soil, especially at harvest time. The low level of soil OC from the application of mineral fertilizer may be because of the fact that synthetic fertilizer application, especially mineral $\mathrm{N}$, favors the growth of soil microorganisms that consume $\mathrm{C}$ than those that can build it (Leu 2007).

The application of both organic and mineral fertilizer resulted in the increase of AP in the soil with no significant interaction effect between them. Organic manures mostly supply $\mathrm{P}$ and micronutrients (Makinde and Agboola 2002) and more than $70 \%$ of the $P$ in animal manure is plant available in its inorganic form (Eghball et al. 2002). By contrast, cassava is efficient in P extraction from the soil because of the symbiotic association between its roots and Vascular-Arbuscular mycorrhiza (Howeler 2001) that can minimizes P depletion. As a result, both application of organic and mineral fertilizer resulted in increased soil AP under the cassava fields.

Numerous researches on soil fertility in cassava reported that cassava extracts more exchangeable $\mathrm{K}$ compared to other crops (Fernandes et al. 2017; Howeler 2002; Howeler et al. 2013; Osundare 2014). Irrespective of the ability of manure to supply exchangeable bases (especially $\mathrm{Ca}^{2+}, \mathrm{Mg}^{2+}$, and $\mathrm{K}^{+}$) and the nearly $100 \%$ availability of $\mathrm{K}$ from manure (Eghball et al. 2002), the increase in soil $\mathrm{K}$ between the different levels of manure was non-significant in this research. To the opposite, the application of organic manure significantly increased other exchangeable cations in the soil. This may be considered as the confirmation of the high $\mathrm{K}$ demand of cassava from this research also. $\mathrm{K}$ is the most limiting factor in cassava system (Ezui 2017), and it was also found that for every single tone of cassava root harvested 2.3, 0.4, and $3.0 \mathrm{~kg}$ of nitrogen, phosphorous and potassium is removed from the soil (Hauser et al. 2014). This shows that $\mathrm{K}$ is not only essential, but it is leading the amount of nutrients removed by cassava roots. The application of mineral fertilizer, on the other hand, significantly improved soil exchangeable $\mathrm{K}$, but significantly reduced the other exchangeable bases. This may be because we applied mineral fertilizer $\mathrm{K}$, but not the other nutrients. Besides to this, the application of chicken manure also improved the CEC of the soil in Zambia. This corroborates what Bakayoko et al. (2009) found in west Africa.

A recent review on secondary and micronutrients study in SSA indicated that regardless of their importance in increasing productivity, secondary and micronutrients were rarely studied; with macronutrients getting the most attention (Kihara et al. 2017). The review also indicated that application of $\mathrm{S}$ and micronutrients increased maze yield by $25 \%$ and its agronomic efficiency improvement varied between 38 and $432 \mathrm{~kg} \mathrm{~kg}^{-1}$ compared to the use of macronutrients alone. Though, micronutrient deficiency reports from cassava fields are very few, B, $\mathrm{Cu}, \mathrm{Fe}$, and $\mathrm{Mn}$, deficiencies were reported from calcareous soils with high $\mathrm{pH}$ level, while $\mathrm{Zn}$ deficiency were reported both under acidic and alkaline soils (Howeler 2011). However, because of the fact that micronutrients deficiency and disease symptoms are most of the time similar, it is hard to detect micronutrients deficiencies in cassava fields (Hauser et al. 2014). In this research, the application of chicken manure improved all the micronutrient status in the soil, with significant improvement observed for $\mathrm{Zn}$ content in the soil. To the opposite, while $\mathrm{Zn}$ and $\mathrm{Cu}$ content in the soil declined, soil $\mathrm{Mn}$ and Fe content significantly improved with the application of mineral fertilizer, mainly at 8 and 12 MAP. A research from Malesia revealed that $\mathrm{Cu}$ was found to be the most limiting micronutrient for cassava production (Chew et al. 2008). In this research, the $\mathrm{Cu}$ released to the soil was statistically not significant following manure application-where we expect $\mathrm{Cu}$ release to the soil, while it was significantly reduced for the soils treated by NPK fertilizer-where we did not applied $\mathrm{Cu}$. This may indicate that $\mathrm{Cu}$ is still important micronutrient for cassava production from this research too.

\section{Conclusion}

It was evidenced that in an integrated system that uses both organic and mineral fertilizer, the soil nutrient level improves to support more crops sustainably. In this research, chicken manure application and its combination with mineral fertilizer improved the soil nutrient condition than mineral fertilizer application in most cases. While soil pH level improved with the application of manure, it declined with the application of mineral fertilizer application. In similar fashion, OC and TN increased with the application of manure. But, they declined with the application of mineral fertilizer. However, their combination improved both $\mathrm{OC}$ and TN, especially at harvest time. Manure application appreciably improved the soil $\mathrm{Zn}$ content, but soil $\mathrm{Cu}$ level declines with the application of mineral fertilizer to cassava fields. Therefore, it is concluded from this research that either sole manure application or its combination with mineral fertilizer improves the soil nutrient status in cassava fields.

\footnotetext{
Abbreviations

AAS: atomic absorption spectrophotometry; ANOVA: analysis of variance; AP: available phosphorous; CEC: cation exchange capacity; GLMM: generalized linear mixed model; HSD: honestly significant difference; IITA: International Institute of Tropical Agriculture; MAP: months after planting; OC: organic carbon; RCBD: randomized complete block design; SARD-SC: Support to
} 
Agricultural Research for Development of Strategic Crops in Africa; SSA: sub-Saharan Africa; TN: total nitrogen; ZARI: Zambian Agricultural Research Institute; ZEMA: Zambian Environmental Management Authority.

\section{Authors' contributions}

GKB conceived, designed, collected the data, analyzed and wrote the manuscript. EE and PN supervised the inception, design and edited the manuscript. PN facilitated the logistics and supervised the data collection process in Zambia. All authors read and approved the final manuscript.

\section{Author details}

${ }^{1}$ Center for Environmental Science, College of Natural and Computational Science, Addis Ababa University, P O box 3131, Addis Ababa, Ethiopia. ${ }^{2}$ International Institute of Tropical Agriculture (IITA), Plot 1458B Ngwerere Road, P O Box 310142, Chelston, Lusaka, Zambia. ${ }^{3}$ Department of Natural Resource Management, College of Agriculture and Veterinary Science, Ambo University, P O box 19, Ambo, Ethiopia.

\section{Acknowledgements}

The authors would like to thank IITA's Support to Agricultural Research for Development of Strategic Crops in Africa (SARD-SC) project for funding this research and Zambian Agricultural Research Institute (ZARI) Mansa staff and officials for their cooperation during the whole study period and for allowing us to use their farm plots. We thank also Dr. Tesfaye Shiferaw Sida for his comment and edition of this manuscript.

\section{Competing interests}

The authors declare that they have no competing interests.

\section{Availability of data and materials}

The data used in this paper is with the authors and can be available upon demand.

\section{Consent for publication}

Not applicable.

\section{Ethics approval and consent to participate}

Not applicable.

\section{Funding}

This research was funded by SARD-SC cassava project of IITA.

\section{Publisher's Note}

Springer Nature remains neutral with regard to jurisdictional claims in published maps and institutional affiliations.

Received: 9 November 2018 Accepted: 18 January 2019

Published online: 21 January 2019

\section{References}

Amanullah MM, Vaiyapuri K, Sathyamoorthi K, Pazhanivelan S, Alagesan A (2007) Nutrient uptake, tuber yield of cassava (Manihot esculenta Crantz.) and soil fertility as influenced by organic manures. J Agron 6:183-187

Anderson JM, Ingram JSI (1993) Tropical soil biology and fertility: a handbook of methods, 2nd edn. CAB International, The Cambrian News

Anyanwu CN, Ibeto CN, Ezeoha SL, Ogbuagu NJ (2015) Sustainability of cassava (Manihot esculenta Crantz) as industrial feedstock, energy and food crop in Nigeria. Renew Energy 81:745-752. https://doi.org/10.1016/j. renene.2015.03.075

Aregheore EM (2009) Country pasture/forage resource profiles: Zambia, Agricultural Organization of the United Nations (FAO). FAO, Italy

Ayoola OT, Makinde EA (2014) Soil nutrient dynamics, growth and yield of green maize and vegetable cowpea with organic-based fertilization. Archiv Agron Soil Sci 60:183-194. https://doi.org/10.1080/03650 340.2013 .775422

Bakayoko S, Soro D, Nindjin C, Dao D, Tschannen A, Girardin O, Assa A (2009) Effects of cattle and poultry manures on organic matter content and adsorption complex of a sandy soil under cassava cultivation (Manihot esculenta Crantz.). Afr J Environ Sci Technol 3:190-197

Bates D, Maechler M, Bolker B, Walker S (2015) Fitting linear mixed-effects model using Ime4. J Stat Softw 67:1-48. https://doi.org/10.18637/jss. V067.101

Bationo A, Kihara J, Vanlauwe B, Waswa B, Kimetu J (2007) Soil organic carbon dynamics, functions and management in West African agro-ecosystems. Agric Syst 94:13-25. https://doi.org/10.1016/j.agsy.2005.08.011

Bationo A, Waswa B, Okeyo JM, Maina F, Kihara J, Mokwunye U (eds) (2011) Fighting poverty in sub-Saharan Africa: the multiple roles of legumes in integrated soil fertility management. Springer, Berlin

Biratu GK, Elias E, Ntawuruhunga P, Nhamo N (2018) Effect of Chicken Manure Application on Cassava Biomass and Root Yields in Two Agro-Ecologies of Zambia. Agriculture 8:45

Bodruzzaman M (2010) Long-term effects of applied organic manures and inorganic fertilizers on yield and soil fertility in a wheat-rice cropping pattern, 19th World Congress of Soil Science. Soil Solutions for a Changing World, Brisbane

Brady NC, Weil RR (2002) The nature and properties of soil, 13th edn. Prentice Hall, New Jersey

Buondonno AA, Rashad AA, Coppola E (1995) Comparing tests for soil fertility. 11. The hydrogen peroxide/sulfuric acid treatment as an alternative to the copper/selenium catalyzed digestion process for routine determination of soil nitrogen-Kjeldahl. Commun Soil Sci Plant Anal 26:1607-1619

Carsky RJ, Toukourou MA (2005) Identification of nutrients limiting cassava yield maintenance on a sedimentary soil in southern benin, west africa. Nutr Cycl Agroecosyst 71:151-162. https://doi.org/10.1007/s1070 5-004-1803-9

Chew WY, Joseph KT, Ramli K (2008) Influence of soil-applied micronutrients on cassava (Manihot esculenta) in Malaysian Tropical Oligotrophic Peat. Exp Agric 14:105-112. https://doi.org/10.1017/S0014479700008498

Chianu JN, Chianu JN, Mairura F (2012) Mineral fertilizers in the farming systems of sub-Saharan Africa. A review. Agron Sustain Dev 32:545-566. https://doi.org/10.1007/s13593-011-0050-0

Edet MA, Tijani-Eniola H, Okechukwu RU (2013) Residual effects of fertilizer application on growth and yield of two cassava varieties in Ibadan, southwestern Nigeria. AJRTC 10:33-40

Eghball B, Wienhold BJ, Gilley JE, Eigenberg RA (2002) Mineralization of manure nutrients. J Soil Water Conserv 57:470-473

Elias E (2016) Soils of the Ethioian highlands: geomorphology and properties capacity building for scaling up of evidence-based best practices for increased agricultural production in Ethiopia (CASCAPE). Wageningen University, Wageningen

Ezui KS (2017) Understanding the productivity of cassava in West Africa, production ecology and resource conservation-PE \& RC. Wageningen University, Wageningen, p 193

Fairhurst T. (Ed.) (2012) Handbook for integrated soil fertility management, India

FAO (2008) Country report on the state of plant Genetic resources for food and agriculture: Zambia. In: Mwila GP et al (eds) FAO Commission on Genetic Resources for Food and Agriculture. FAO, Rome

Fernandes AM, Gazola B, Nunes JG, Garcia EL, Leonel M (2017) Yield and nutritional requirements of cassava in response to potassium fertilizer in the second cycle. J Plant Nutr 40:2785-2796. https://doi.org/10.1080/01904 167.2017.1382520

Hauser S, Wairegi L, Asadu CLA, Asawalam DO, Jokthan G, Ugbe U (2014) Cassava system cropping guide Africa Soil Health Consortium. Nirobi, Kenya

Haynes RJ, Mokolobate MS (2001) Amelioration of Al toxicity and P deficiency in acid soils by additions of organic residues: a critical review of the phenomenon and the mechanisms involved. Nutr Cycl Agroecosyst 59:47-63. https://doi.org/10.1023/a:1009823600950

Hazelton P, Murphy B (2007) Interpreting soil test results: What do all the numbers mean?. CSIRO, NSW Department of Natural Resources, Australia

Heanes DL (1984) Determination of organic C in soils by an improved chromic acid digestion and spectrophotometric procedure. Commun Soil Sci Plant Anal 15:1191-1213

Howeler R.H. (2001) Nutrient inputs and losses in cassava-based cropping systems: examples from Vietnam and Thailand, International Workshop on Nutrient Balances for Sustainable Agricultural Production and Natural Resource Management in Southeast Asia, Bangkok, Thailand 
Howeler RH (2002) Cassava mineral nutrition and fertilization. In: Hillocks RJ et al (eds) Cassava: biology, production and utilization, CABI. Cali, Colombia

Howeler RH (2011) Effect of cassava production on soil fertility and the longterm fertilizer requirements to maintain high yields. In: Howeler RH (ed) The cassava handbook: a reference manual based on the asian regional cassava training course, held in thailand, Centro Internacional de Agricultura Tropical (CIAT). Cali, Colombia

Howeler RH (2014) Sustainable soil and crop management of cassava in Asia. The International Center for Tropical Agriculture (CIAT), Cali, Colombia

Howeler RH, Lutaladio N, Thomas G (2013) Save and grow: cassava-a guide to sustainable production intensification. Food and Agricultural Organization of the United Nations (FAO), Rome, Italy., p 142

Imas P, John KS (2013) Potassium nutrition of cassava. International potash institure e-ifc No. 34

Islam AKMS, Edwards DG, Asher CJ (1980) pH optima for crop growth. Plant Soil 54:339-357. https://doi.org/10.1007/bf02181830

JAICAF (2008) Agriculture and forestry in Zambia: present situation and issues for development, Japan Association for International Collaboration of Agriculture and Forestry (JAICAF). JAICAF, Tokyo

Kihara J, Sileshi GW, Nziguheba G, Kinyua M, Zingore S, Sommer R (2017) Application of secondary nutrients and micronutrients increases crop yields in sub-Saharan Africa. Agron Sustain Dev 37:25. https://doi. org/10.1007/s13593-017-0431-0

Lenth RV (2016) Least-squares means: the R package Ismeans. J Stat Softw 69:1-33. https://doi.org/10.18637/jss.v069.i01

Leu A (2007) Organics and soil carbon: increasing soil carbon, crop productivity and farm profitability. Managing the Carbon Cycle- Katanning Workshop, Citeseer, pp 19-26

Makinde EA, Agboola AA (2002) Soil nutrient changes with fertilizer type in cassava-based cropping system. J Plant Nutr 25:2303-2313. https://doi. org/10.1081/PLN-120014077

McLean EO (1982) Soil pH and lime requirement in: A. L. Page (Ed.) Methods of soil analysis. Chemical and microbiological properties. Part 2. Agronomy Siries No. 9, ASA, SSSA, Madison, USA. pp. 199-234

Mehlich M (1984) Mehlich 3 soil test extractant: a modification of the Mehlich 2 extractant. Commun Soil Sci Plant Anal 15:1409-1416
Morris M, Kelly VA, Kopicki RJ, Byerlee D (2007) Fertilizer use in African agriculture: Lessons learned and good practice guidelines. The World Bank, Washington

Namoi NL, Onwonga RN, Onyango CM, Karuku GN, Kathumo VM (2014) Assessment of soil nutrient balances in organic based cassava (Manihot esculenta Crantz) and sorghum (Sorghum bicolor (L.) Moench) cropping systems of Yatta Subcounty, Kenya. Am Jf Exp Agric 4:1557-1578. https:// doi.org/10.9734/AJEA/2014/10230

Ntawuruhunga P, Chiona M, Manda N, Korie S, Njobvu J (2013) Assessment of performance and farmers' preference varieties through participatory variety selection and calls for doubling breeding effort in Zambia. In: Okechukwu RU et al (eds) 12th triennial symposium of international society for tropical root crops-Africa Branch (ISTRC-AB). Accra, Ghana, p 173

Osundare B (2014) Observations on cassava (Manihot esculenta Crantz) root yield and soil fertility under different K-sources. J Biol Agric Healthc 4:81-86

Pongsivapai P, Thongjoo C, Romkaew J, Inboonchuay T (2016) Effect of fertilizer management in combination with soil conditioner on yield of cassava cultivated on coarse-textured soil in thailand. Modern Appl Sci 10:239-247

R Core Team (2017) R: A language and environment for statistical computing $R$ foundation for statistical computing, Vienna

Rós AB, Hirata ACS, Narita N (2013) Cassava roots yield and soil chemical and physical properties according to chicken manure fertilization. Pesquisa Agropecuária Tropical 43:247-254. https://doi.org/10.1590/\$1983-40632 013000300001

Salami BT, Sangoyomi TE (2013) Soil Fertility Status of Cassava Fields in South Western Nigeria. Am J Exp Agric 3:152-164

Sileshi GW, Nhamo N, Mafongoya PL, Tanimu J (2017) Stoichiometry of animal manure and implications for nutrient cycling and agriculture in sub-Saharan Africa. Nutr Cycl Agroecosyst 107:91-105. https://doi.org/10.1007/ s10705-016-9817-7

van Reeuwijk LP (ed) (2002) Procedures for soil analysis, International Soil Reference and Information Center (ISRIC). ISRIC, Wageningen

ZEMA (2013) Mansa district state of environment outlook report. Manin report in 2013, Zambia

\section{Submit your manuscript to a SpringerOpen ${ }^{\circ}$ journal and benefit from:}

- Convenient online submission

- Rigorous peer review

- Open access: articles freely available online

- High visibility within the field

- Retaining the copyright to your article

Submit your next manuscript at $\boldsymbol{\nabla}$ springeropen.com 